\title{
Risk of developmental delay of children aged between two and 24 months and its association with the quality of family stimulus
}

\author{
Risco de atraso no desenvolvimento de crianças de dois a 24 meses e sua associação com a qualidade \\ do estímulo familiar
} Riesgo de retardo en el desarrollo de niños de dos a 24 meses y su asociación con la calidad del
estímulo familiar

Alessandro Fernandes Guimarães ${ }^{1}$, Davi Vilela de Carvalho², Nathália Ádila A. Machado1, Regiane Aparecida N. Baptista1, Stela Maris A. Lemos ${ }^{1}$

\section{ABSTRACT}

Objective: To analyze the association between neurodevelopment and the family environment resources of children from the coverage area of a Basic Health Unit (BHU) of Belo Horizonte, Brazil, using a tool based on the Integrated Management of Childhood Illness (IMCI) strategy.

Methods: Cross-sectional study with a non-probabilistic sample involving 298 children aged between 2-24 months old, who attended a BHU in 2010. The assessment of child development and family resources made at the BHU lasted, in average, 45 minutes and included two tests - an adaptation of the Handbook for Monitoring Child Development in the Context of IMCI and an adapted version of the Family Environment Resource (FER) inventary. The nonparametric tests of Kruskal-Wallis and Mann-Whitney were used for the statistical analysis.

Results: The sample included 291 assessments, with $18.2 \%$ of children between 18 and 24 months old, $53.6 \%$ male gender, and $91.4 \%$ who did not attend day care centers. According to IMCI, $31.7 \%$ of the children were in the risk group for developmental delay. The total average score in FER was 38.0 points. Although it has been found an association between the IMCI outcome and the total FER score, all groups had low scores in the family environment assessment.

Instituição: Programa PET-Saúde da Universidade Federal de Minas Gerais (UFMG), Belo Horizonte, MG, Brasil

${ }^{1}$ Faculdade de Medicina da UFMG, Belo Horizonte, MG, Brasil ${ }^{2}$ Núcleo de Apoio à Saúde da Família (NASF) da Prefeitura Municipal de Belo Horizonte, Belo Horizonte, MG, Brasil
Conclusions: The data indicate the need for childhood development screening in the primary health care and for early intervention programs aimed at this age group.

Key-words: child development; primary health care; Integrated Management of Childhood Illness; family relations.

\section{RESUMO}

Objetivo: Analisar a associação entre o desenvolvimento neuropsicomotor e os recursos do ambiente familiar de crianças da área de abrangência de uma Unidade Básica de Saúde (UBS) de Belo Horizonte, utilizando instrumento baseado na estratégia Atenção Integral das Doenças Prevalentes na Infância (AIDPI).

Métodos: Estudo transversal com amostra não probabilística, do qual participaram 298 crianças de dois a 24 meses que frequentavam uma UBS de Belo Horizonte, em 2010. A avaliação do desenvolvimento infantil e dos recursos familiares feita na UBS teve duração média de 45 minutos e incluiu a aplicação de dois testes - uma adaptação do Manual para Vigilância do Desenvolvimento Infantil no Contexto da AIDPI e uma versão adaptada do Inventário de Recursos do Ambiente Familiar (RAF). Na análise estatística, utilizaram-se os testes não paramétricos de Kruskal-Wallis e de Mann-Whitney.

Endereço para correspondência:

Stela Maris A. Lemos

Avenida Alfredo Balena, 190, sala 251 - Santa Efigênia

CEP 30130-100 - Belo Horizonte/MG

E-mail: lemos.stela@gmail.com

Fonte financiadora: Ministério da Saúde - PET-Saúde da UFMG

Conflito de interesse: nada a declarar

Recebido em: 8/12/2012

Aprovado em: 3/6/2013 
Resultados: A amostra conteve 291 avaliações, sendo maiores as porcentagens de crianças de 18 a 24 meses $(18,2 \%)$, do sexo masculino $(53,6 \%)$ e que não frequentavam creche $(91,4 \%)$. Os resultados obtidos com a AIDPI demonstraram que $31,7 \%$ das crianças estavam em um grupo de risco para o atraso no desenvolvimento. No Inventário RAF, a pontuação total média foi de 38,0 pontos. Embora tenha havido associação do resultado da AIDPI com a pontuação total obtida no Inventário RAF, todos os grupos apresentaram baixa pontuação na avaliação do ambiente familiar.

Conclusões: Os dados apontam para a necessidade de triagem do desenvolvimento infantil na atenção básica e de programas de intervenção precoce voltados para essa faixa etária.

Palavras-chave: desenvolvimento infantil; atenção primária à saúde; Atenção Integrada às Doenças Prevalentes na Infância; relações familiares.

\section{RESUMEN}

Objetivo: Analizar la asociación entre el desarrollo neuropsicomotor y los recursos del ambiente familiar de niños de dos a 24 meses del área de alcance de una Unidad Básica de Salud (UBS) de Belo Horizonte, utilizando instrumento basado en la estrategia Atención Integral de las Enfermedades Prevalentes en la Infancia (AIDPI).

Métodos: Estudio transversal con muestra no probabilística, del que participaron 298 niños de dos a 24 meses y que frecuentaban una UBS de Belo Horizonte, en 2010. La evaluación del desarrollo infantil y de los recursos familiares realizada en la UBS tuvo duración mediana de 45 minutos e incluyó la aplicación de dos pruebas - una adaptación del Manual para Vigilancia del Desarrollo Infantil en el Contexto de AIDPI y una versión adaptada del Inventario de Recursos del Ambiente Familiar (RAF). En el análisis estadístico, se utilizaron las pruebas no paramétricas de Kruskal-Wallis y de Mann-Whitney.

Resultados: La muestra contuvo 291 evaluaciones, siendo más grandes los porcentajes de niños de 18 a 24 meses $(18,2 \%)$, del sexo masculino $(53,6 \%)$ y que no frecuentaban guardería $(91,4 \%)$. Los resultados obtenidos con la AIDPI demostraron que el $31,7 \%$ de los niños estaban en un grupo de riesgo para el retardo en el desarrollo. En el Inventario de RAF, la puntuación total mediana fue de 38,0 puntos. Aunque haya habido asociación del resultado de AIDPI con la puntuación total obtenida en el Inventario de RAF, todos los grupos presentaron baja puntuación en la evaluación del ambiente familiar.

Conclusiones: Los datos apuntan a la necesidad de rastreo del desarrollo infantil en la atención básica y de programas de intervención temprana dirigidos a esa franja de edad.

Palabras clave: desarrollo infantil; atención primaria a la salud; Atención Integrada a las Enfermedades Prevalentes en la Infancia; relaciones familiares.

\section{Introduction}

Children have different opportunities during their development due to their personal attributes and the social environment in which they live. In line with this observation, Bronfebrenner proposed the Ecological Theory of Development, which suggested a model of child development based on the processes of complex, reciprocal, and gradual interaction between the child and all levels of environmental influence ${ }^{(1)}$. Thus, child development is considered a multifactorial process, resulting from the combination of biological, environmental, family, and social factors, of risk or protection, culminating in a unique and peculiar development ${ }^{(2)}$. The importance of the cumulative effect of these multiple influences in the development should be admitted, instead of considering it only a basically biological perspective, since in countries with significant socioeconomic inequality, such as Brazil, children are exposed to multiple negative environmental and social impacts, such as poverty and violence ${ }^{(2)}$.

The family environment and its relationships constitute the basis for promoting social-emotional development and cognitive development. Thus, the family can act as stimulating and protector of this process by providing varied quality experiences and interaction with adults and children. However, it may also constitute a risk factor, when the infant is deprived of a well-structured family environment and with appropriate stimuli(3).

Among the various risk factors in the family environment, there is low maternal education, presence of parental depression, living with alcoholics or drug addicts, the use of unsuitable toys for the age group, the lack of early socialization outside the family, low income, and the fact of belonging to disorganized, numerous families, with a level of permanent tension, or little stimulating ${ }^{(3-6)}$. Some of the biological risk factors are low birth weight, gestational age less than 37 weeks and complications in the pre-, peri- and postnatal development ${ }^{(5)}$. 
Protective factors are important tools to develop the ability to respond positively to adversity or stress and reduce the impact of risk factors ${ }^{(5,7)}$. Among the protective biological factors, we may cite autonomy, curiosity in exploring objects, positive personality, reciprocity in social interactions, and intelligence above average. Among environmental factors, are socializing with other children and people outside the family, access to medical and psychological care, religiosity, and participation in cultural activities such as those related to music, theater, and reading ${ }^{(5,7,8)}$.

The Family Environment Resource Inventory (FERI), proposed by the literature ${ }^{(1)}$ to assess the "family environment resources that may contribute to learning in the elementary school years", is an important tool to evaluate the family environment. The Handbook for Monitoring Child Development in the context of Integrated Management of Childhood Illness (IMCI) was created as an attempt to improve the treatment of illnesses that occur in childhood and brings the possibility to improve the identification of gaps in child neurodevelopment ${ }^{(9)}$. The use of this instrument allows the child with identified risk factors or delay to be referred to the appropriate professional or receive guidance, avoiding the combination of developmental delays, culminating in a worse quality of life for the individual in the short and long term. The Handbook for Monitoring Child Development in the context of IMCI can be applied in an epidemiological analysis of the most prevalent profile in a population, grounding adequate approaches to reduce the prevalence of developmental delays in that area, and, in a different moment, it also serves as an instrument to determine the effectiveness of these behaviors.

Given the importance of early detection of delayed child development, this study examined the association between neuropsychomotor development and family environment resources in children from 2 to 24 months old from a Basic Health Unit (BHU) in Belo Horizonte, state of Minas Gerais, using the instrument based on the IMCI strategy.

\section{Method}

Cross-sectional study within the Project Education through Labor (Programa de Educaşão pelo Trabalbo - PET-Saúde), in the line of research Comprehensive Child Healthcare (Cuidado Integral à Saúde da Criança), developed through a partnership of Universidade Federal de Minas Gerais (UFMG) with the Municipal Health Secretariat of Belo Horizonte. The research took place at a Basic Health Unit, located in regional Venda
Nova, in the municipality of Belo Horizonte, in a district that covers a population of 23,883 people $(505$ children from zero to 24 months $\left.^{(10)}\right)$ and has an Index of Health Vulnerability ranging from low to very high ${ }^{(11)}$.

In 2010, 298 children were evaluated, totaling 337 assessments. Because it was a cross-sectional analytical study with a non-probabilistic sample, only one test of each infant was considered, and, therefore, 39 questionnaires were excluded; in addition to these, seven were disregarded due to lack of data.

The evaluations were made by the monitors of the project, students attending health courses at UFMG, who received training based on the literature, such as the Handbook of Infant Developmental Surveillance in the context of IMCI, and training from the preceptors of BHU.

We selected subjects randomly, by invitation to families and caregivers who were receiving treatment at the UBS. Subjects were also selected from two national immunization campaigns and then from childcare. In all cases, participation was voluntary and without any harms to the treatment of the infant. Exclusion criteria were: not being in the age group from 2 to 24 months, not living in the area covered by the Basic Health Unit or having a diagnosis of neurological disease and developmental impairment. The mean time of assessments was 45 minutes. The questionnaires were administered in the form of semi-structured interviews, with questions asked orally to the mother or other responsible, initially as open questions. The instruments used were adapted from the Handbook for Monitoring Child Development in the context of IMCI and the FERI.

The test based on IMCI was divided into three parts: a history of parental perception regarding the infant's development and investigation of the presence of risk factors, an observation of the child constitutional factors and an assessment of developmental milestones. To investigate the developmental milestones, the sample was divided into seven age groups and each was evaluated for four marks, except in the range from 18 to 24 months, in which we assessed eight. These milestones addressed aspects of fine and coarse development, language, and personal-social interaction. As the sample contained premature infants, the age of this group was adjusted so that their results were not underestimated. Head circumference measurements were performed only by preceptors (physicians, nurses, or dentist from the BHU).

The evaluation of the environment and family resources was done through an adaptation of the FERI. This instrument has three broad domains: resources that promote proximal processes; activities that signal stability in family life, parental practices 
that promote a family-school connection. To adapt it to the research, we used only the first two fields, excluding also the items targeted to children outside the age range covered by the study. Thus, the family conditions of children were verified, comparing the performance of infants in this evaluation with the results obtained in the IMCI.

The descriptive results were obtained by frequencies and percentages for categorical variables, and measures of central tendency (mean and median) and measures of dispersion (standard-deviation, 1st quartile and 3rd quartile), for quantitative variables. To verify the association between the score obtained by the domains of FERI, the ungrouped classification of IMCI (normal, normal with risk factors, possible delay and probable delay) and grouped (normal or normal with risk factors and possible or probable delay) were used, respectively, the non-parametric Kruskal-Wallis and Mann-Whitney tests. Significance was established at $5 \%^{(12)}$.

Table 1 - Characteristics of the population $(n=291)$

\begin{tabular}{lrr}
\hline & $\mathbf{n}$ & \multicolumn{1}{c}{$\%$} \\
\hline Age (months) & & \\
2 to 4 & 52 & 17.9 \\
4 to 6 & 31 & 10.7 \\
6 to 9 & 48 & 16.5 \\
9 to 12 & 45 & 15.5 \\
12 to 15 & 39 & 13.4 \\
15 to 18 & 23 & 7.9 \\
18 to 24 & 53 & 18.2 \\
Sex & & \\
$\quad$ Male & 156 & 53.6 \\
Female & 135 & 46.4 \\
Current or previous & & \\
attendance to childcare & & \\
$\quad$ Yes & 25 & 8.6 \\
$\quad$ No & 266 & 91.4 \\
\hline
\end{tabular}

${ }^{*}$ Frequência atual ou pregressa

Table 2 - Test results based on the Strategy of Integrated Management of Childhood IIIness

\begin{tabular}{lrc}
\hline & $\mathbf{n}$ & \% \\
\hline Classification of Child Development & & \\
Probable delay & 55 & 19.2 \\
Possible delay & 36 & 12.5 \\
$\quad$ Normal with risk factors & 107 & 37.3 \\
$\quad$ Normal & 89 & 31.0 \\
Classification grouped in child development & & \\
$\quad$ Probable of possible delay & 91 & 31.7 \\
$\quad$ Normal or normal with risk factors & 196 & 68.3 \\
\hline
\end{tabular}

The analysis of the database was performed in the PASW Statistics software, version 18.0.

This study was approved by the Research Ethics Committee of the municipality of Belo Horizonte and the Research Ethics Committee of UFMG, in the opinion ETIC410/09.

\section{Results}

Among the 291 children assessed, $53.6 \%$ were male. The most prevalent age group was 18 to 24 months (18.2\%) and $91.4 \%$ of the sample did not attend daycare. In Table 1 , the characteristics of the sample are described.

In the result of the IMCI tests, $68.3 \%$ of children were classified as normal; of whom, $37.3 \%$ had, at least, one risk factor, while $31.7 \%$ were in the most susceptible group to present developmental delays, being $19.2 \%$ classified as a probable delay (Table 2). In Table 2, we chose to present the results in two ways. The first, as recommended by the IMCI Handbook, and the second, in a grouped manner. This grouping was performed, because one of the objectives of the study was to assess the occurrence of abnormal development, considering a normal group, regardless of the presence of risk factors, and another with risk of delay, regardless of the degree of delay.

For the FERI, two domains and a total score were assessed. In domain 1, the maximum score was 40 and the minimum, zero. From children evaluated, $50 \%$ had a score of 20.7 and $25 \%$ had up to 16.4 . In domain 2 , the maximum score was

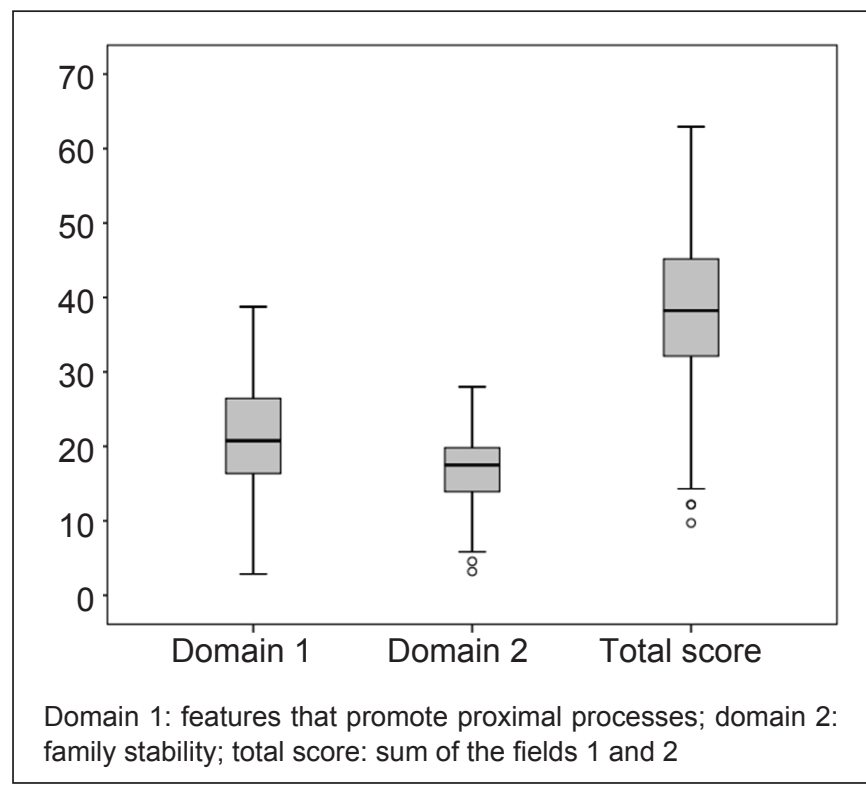

Graph 1 - Boxplot of Family Environment Resources Inventory (FERI) per domain and total score 
30 and the minimum, zero. Among the children analyzed, $50 \%$ had up to 17.5 and $25 \%$ up to 13.9 . For the total score, the maximum possible value was 70 and the minimum, zero (Graph 1).

In the analysis of the association between the results obtained with the IMCI and the score obtained by the FERI, significance was observed only for the total score $(p$ - value $=0.027 ;$ Tables 3 and 4$)$.

\section{Discussion}

The data indicate that about one third of the children were at high risk for developmental delay. Given this high prevalence, it is important to expand the application of screening tests in primary care to identify and intervene as soon as possible to improve the quality of life of children and their families ${ }^{(9)}$. Another important point is to increase the supply of maternal health education to provide an adequate stimulus to their children ${ }^{(2,3)}$. It should be noted that the IMCI Handbook is a screening tool. Thus, diagnostic tests should be performed, besides child monitoring and family counseling to change this scenario.

These findings corroborate the literature ${ }^{(2,13)}$, for longitudinal studies showed similar results, ranging from 20.5 to $34 \%$
Table 4 - Association between the score obtained by the domains of the Family Environment Resources Inventory (FERI) and the grouped classification of the tests based on the Integrated Management of Childhood Illness (IMCl) strategy.

\begin{tabular}{lccc}
\hline & \multicolumn{3}{c}{ Results obtained by the IMCI } \\
\cline { 2 - 4 } & $\begin{array}{c}\text { Normal or } \\
\text { normal with } \\
\text { risk factor }\end{array}$ & $\begin{array}{c}\text { Probable or } \\
\text { possible } \\
\text { delay }\end{array}$ & p-value* \\
\hline Domain 1 & 2.9 & 4.0 & 0.058 \\
$\quad$ Minimum & 20.1 & 23.3 & \\
Median & 20.6 & 22.1 & \\
Mean & 6.8 & 7.2 & \\
SD & 38.7 & 35.9 & 0.156 \\
Maximum & & & \\
Domain 2 & 3.2 & 6.9 & \\
Minimum & 17.1 & 18.1 & \\
Median & 16.8 & 17.4 & \\
Mean & 4.2 & 4.4 & \\
SD & 28.0 & 26.8 & \\
Maximum & & & 0.032 \\
Total score & 14.3 & 12.2 & \\
Minimum & 37.1 & 41.5 & \\
Median & 37.4 & 39.5 & \\
Mean & 9.1 & 10.3 & \\
DP & 62.9 & 62.8 & \\
Maximum &
\end{tabular}

*Non-parametric Mann-Whitney test

Table 3 - Association between the score obtained by the domains of the Family Environment Resources Inventory and the classification of the tests based on the strategy of Integrated Management of Childhood Illnesses

\begin{tabular}{|c|c|c|c|c|c|}
\hline & \multicolumn{5}{|c|}{ Classification in the IMCI } \\
\hline & Normal & $\begin{array}{l}\text { Normal with } \\
\text { risk factor }\end{array}$ & Possible delay & Probable delay & $p$-value* \\
\hline Domain 1 - FERI & & & & & 0.139 \\
\hline Minimum & 6.1 & 2.9 & 4.0 & 5.1 & \\
\hline Median & 19.6 & 20.7 & 22.9 & 23.7 & \\
\hline Mean & 20.0 & 20.9 & 21.3 & 22.7 & \\
\hline SD & 6.4 & 7.2 & 7.1 & 7.4 & \\
\hline Maximum & 38.7 & 34.0 & 35.9 & 35.7 & \\
\hline Domain 2 - FERI & & & & & 0.051 \\
\hline Minimum & 3.2 & 7.3 & 6.9 & 7.1 & \\
\hline Median & 17.0 & 17.7 & 16.5 & 18.8 & \\
\hline Mean & 16.5 & 17.2 & 16.2 & 18.3 & \\
\hline SD & 4.1 & 4.3 & 4.8 & 4.0 & \\
\hline Maximum & 24.5 & 28.0 & 26.9 & 25.8 & \\
\hline Total Score - FERI & & & & & 0.027 \\
\hline Minimum & 16.6 & 14.3 & 12.2 & 12.2 & \\
\hline Median & 36.4 & 38.0 & 38.1 & 42.1 & \\
\hline Mean & 36.7 & 38.2 & 37.5 & 41.0 & \\
\hline SD & 8.7 & 9.6 & 10.5 & 10.1 & \\
\hline Maximum & 62.9 & 58.8 & 62.8 & 59.0 & \\
\hline
\end{tabular}

*Non-parametric Kruskal-Wallis test; SD: standard-deviation; IMCI: Integrated Management of Childhood IIInesses 
of children at risk for developmental delay. In a longitudinal study with a higher prevalence of delay ${ }^{(2)}$, it was detected at least one screening test changed in at least one application. It should be noted that this study had a limit of age of 12 months ${ }^{(2)}$. The investigation with lower prevalence of delay ${ }^{(13)}$ also assessed children of up to 12 months and used the Denver Developmental Screening Test II as an instrument.

The results showed an association between the result of the IMCI and the total score obtained in the FERI $(p=0.027)$, although all groups have presented low scores in the assessment of the family environment and median values. This relationship is consistent with the literature, once studies demonstrated that the variable with the greatest impact on child development is environmental stimulation ${ }^{(3,14-16)}$. The manner in which parents organize the physical environment and interact with the children directly influences the child's development ${ }^{(14,15)}$. Therefore, the better the quality of stimulation available to the child, the better his or her cognitive performance ${ }^{(16)}$.

In this context, we should consider educational institutions in the discussion of child development ${ }^{(17)}$. Studies showed that infants enter these environments with approximately 3 months old and remain there most of the day ${ }^{(18)}$. It should be remembered that the child is placed in an environment that is supposed to promote development, provided that the institution is well structured and can provide the right incentives and qualified educators. However, if the institution fails to provide timely and appropriate experiences, it may contribute to impaired child development ${ }^{(18,19)}$. It is important, then, to seek certification of school environments that promote a healthy development.

According to the values obtained from the association between the outcome of IMCI and the score obtained in the FERI questionnaire, the group with the best median on this questionnaire was the one including children with probable delay (Table 3). This, however, is not in line with the literature. The difference is possibly due to the methods used in the present study. Among the possible reasons is the fact that a child with a changed head circumference is classified as "probable delay" by IMCI, even if he or she has reached all the milestones of the age range without identification of any risk factors for development. The importance of measuring head circumference is due to its direct correlation with the brain size and, thus, it has a role in detecting anomalies besides being used as a nutrition indicator ${ }^{(20)}$. According to guidelines in the IMCI Handbook, the curves of the National Center for Health Statistics (NCHS) were used. However, more recent studies show that this curve is not the most appropriate, and, today, the World Health Organization (WHO) recommends the use of a curve launched in $2006^{(21,22)}$. Moreover, graphs obtained in international multicenter studies may not necessarily correspond to the peculiar characteristics of a regional population ${ }^{(23-25)}$ and half or more of the variations in head circumference are normal variants of family origin ${ }^{(26,27)}$. It is also worth noting that the IMCI is stricter regarding the normal interval of head circumference, as it uses cutting points between the 10th and the 90th percentiles of the NCHS curve, 2000, an other instruments use a wider cut, such as, for instance, between percentiles 2.3 and $97.7^{(28)}$, or even limits on $\mathrm{Z}$ score $(+2 /-2)$ in most recent curves of the $\mathrm{WHO}^{(29)}$. This IMCI strategy is positive as a population screening, as it ensures fewer false-negative results for developmental disorders. On the other hand, it generates greater risk of classifying normal children as "probable delay".

Although this work presents advances, such as the need for early identification of children at risk of developmental delay and the importance of the application of screening tests in primary care, the cross-sectional design does not allow the analysis of the cause and effect, i.e., if the neuropsychomotor development of children stems from stimulation in the home environment. Thus, the study only allows investigating the association between these variables. Longitudinal studies are recommended to broaden the causal relationships relevant to the subject studied. Another limitation is the fact that the study assessed only children attending the UBS for reasons of illness, monitoring, or vaccination, even after conducting an active search. This search has been an important strategy in the study, but failed to reach the universe of children living in the area covered by the Unit. So, naturally, those who did not attend the UBS were excluded, besides those who were not allowed to participate in the study by parents or guardians.

According to the guidelines of the IMCI Handbook, some data are guided through subjective analysis and the response of the parent, for instance, information about family life. Still on the analysis of markers, the need to observe whether the infant performs the task during the evaluation time produces the bias of the child being scared with the environment, different than usual, and thus does not perform the task that he or she usually does. It should also be considered the fact that the age divisions of the instruments used in the evaluations have been of at least 2 months, because this period may include many behavioral changes. In an interval of 2 months, in the age range of the study, there are differences that can change a child's performance in assessment scales ${ }^{(12)}$. 
Despite the limitations, given the scenario presented, the Family Health Program emerged as an important alternative for attention to children, because it corresponds to a new concept of health, centered in the promotion of quality of life. Because it has technical potential and human resources to intervene in the family environment, it can contribute significantly to children's development. Furthermore, it is essential that the health professionals, along with the family and the community in which they are inserted, monitor the children's development. It is essential to identify the children that are most at risk as early as possible in order to minimize the negative effects, because the sooner the diagnosis and intervention are made, the lower the impact of these problems in the future ${ }^{(12)}$.

\section{References}

1. Marturano EM. The home enviromment resources scale. Psicol Reflex Crit 2006;19:498-506.

2. Halpern R, Giugliani ER, Victora CG, Barros FC, Horta BL. Risk factors for suspicion of developmental delays at 12 months for age. J Pediatr (Rio J) 2000;76:421-8.

3. Andrade SA, Santos DN. Family environment and child's cognitive development: an epidemiological approach. Rev Saude Publica 2005;39:606-11.

4. Nascimento R, Madureira VS, Agne JE. Evaluation of neurological and psychomotor development in children from baby centers of Concórdia. Rev Neurocienc 2008;16:284-91.

5. Maia JM, Williams LC. Risk and protective factors for child development. Temas Psicol 2005;13:91-103.

6. Amorim RC, Laurentino GE, Barros KM, Ferreira AL, Moura Filho AG, Raposo MC. Family health program: proposal for identification of risk factors for neuropsychomotor development. Rev Bras Fisioter 2009;13:506-13.

7. Sapienza G, Pedromônico MR. Risk, protection and resilience in the development of children and adolescents. Psicol Estud 2005;10:209-16.

8. Wendt NC. Fatores de risco e de proteção para o desenvolvimento da criança durante a transição para parentalidade [tese de mestrado]. Florianópolis (SC): UFSC; 2006.

9. Figueiras AC, Souza IC, Rios VG, Benguigui Y. Manual para vigilância do desenvolvimento infantil no contexto da AIDPI. Washington: OPAS; 2005.

10. Minas Gerais - Prefeitura Municipal de Belo Horizonte [homepage on the Internet]. Estatísticas e indicadores - Censo 2010: população residente total, homens, mulheres e faixa etária por bairros [cited 2012 Aug 28]. Available from: http:// portalpbh.pbh.gov.br/pbh/ecp/files.do?evento=download\&urlArqPIc=des-t033.xls

11. Minas Gerais - Secretaria Municipal de Saúde de Belo Horizonte [homepage on the Internet]. Índice de vulnerabilidade à saúde 2003 [cited 2003 Jul 10]. Available from: http://www.pbh.gov.br/smsa/biblioteca/gabinete/risco2003.pdf

12. Medronho RA, Bloch KV, Luiz RR, Werneck GL. Epidemiologia. $2^{\text {nd }}$ ed. São Paulo: Atheneu; 2009.

13. Veleda AA, Soares MC, Cézar-Vaz MR. Fatores associados ao atraso no desenvolvimento em crianças, Rio Grande, Rio Grande do Sul, Brasil. Rev Gauch Enferm 2011;32:79-85.

14. Andraca I, Pino P, de la Parra A, Rivera Y, Marcela F. Risk factors for psychomotor development among infants born under optimal biological conditions. Rev Saude Publica 1998;32:138-47.

15. Bastos AC, Almeida Filho NM. Variables económicosociales, ambiente familiar y salud mental infantil en un área urbana de Salvador (Bahía), Brasil. Acta Psiquiatr Psicol Am Lat 1990;36:147-54.
The present study showed that, in the evaluation of children from 2 to 24 months old assisted at the UBS, $31.7 \%$ were classified, according to IMCI, in the group with possible and probable delay in the grouped classification - those most at risk for neuropsychomotor developmental delay - and only $31 \%$ were classified as normal, without exposure to risk factors. It should be mentioned that the head circumference curves used by the IMCI Handbook should be updated to meet the new reference values obtained in more recent studies. There was also an association between neurodevelopment and quality of stimulation in the home environment. However, it was not established that children who had adequate neuropsychomotor development had greater resources and stimuli in the family environment than those with risk of delay.

16. Martins MF, Costa JS, Saforcada ET, Cunha MD. Quality of the enviroment and associated factors: a pediatric study in Pelotas, Rio Grande do Sul, Brasil. Cad Saude Publica 2004;20:710-8.

17. Maia JM, Williams LC. Risk and protective factors for child development. Temas Psicol 2005;13:91-103.

18. Baltieri L, Santos DC, Gibim NC, Souza CT, Batistela AC, Tolocka E. Motor performance of infants attending the nurseries of public day care centers. Rev Paul Pediatr 2010;28:283-9.

19. Santos DC, Tolocka RE, Carvalho J, Heringer LR, Almeida CM, Miquelote AF. Gross motor performance and its association with neonatal and familial factors and day care exposure among children up to three years old. Rev Bras Fisioter 2009;13:173-9.

20. Macchiaverni LM, Barros Filho AA. Head circumference: why always measure it? Medicina (Ribeirao Preto) 1998;31:595-609.

21. Jaldin MG, Pinheiro FS, Santos AM, Muniz NC, Brito LM. Head circumference growth of exclusively breastfed infants during the first six months of life. Rev Paul Pediatr 2011;29:509-14.

22. Silveira FJ, Lamounier JA. Nutritional assessment of children of the Jequitinhonha Valley region in Brazil with NCHS and the new WHO growth charts. Rev Paul Pediatr 2009;27:133-8.

23. Mota M, Melo A, Burak C, Daltro C, Rodrigues B, Lucena R. Anthropometric cranial measures of normal newborn. Arq Neuropsiquiatr 2004;62:626-9.

24. Oliveira HA, Paixão AC, Paixão MO, Barros VC. Anthopometric cranial measurements of normal newborn in Sergipe - Northeast of Brazil. Arq Neuropsiquiatr 2007;65:896-9.

25. Schienkiewitz A, Schaffrath Rosario A, Dortschy R, Ellert U, Neuhauser H German head circumference references for infants, children and adolescents in comparison with currently used national and international references. Acta Paediatr 2011;100:e28-33.

26. Weaver DD, Christian JC. Familial variation of head size and adjustment for parental head circumference. J Pediatr 1980;96:990-4.

27. Peñas JJ, Andújar FR. Alteraciones del perímetro craneal: microcefalia y macrocefalia. Pediatr Integral 2003;7:587-600.

28. Grummer-Strawn LM, Reinold C, Krebs NF [homepage on the Internet]. Use of World Health Organization and CDC Growth Charts for children aged 0-59 months in the United States. MMWR Recommendations and Reports [cited 2013 Apr 02]. Available from: http://www.cdc.gov/mmwr/preview/mmwrhtml/ rr5909a1.htm

29. Brasil - Ministério da Saúde. Caderneta de saúde da criança. $7^{\text {th }}$ ed. Brasília: Ministério da Saúde, 2010. 